\title{
Negocjowanie umów o unikaniu podwójnego opodatkowania1
}

\section{Wprowadzenie}

W ostatnich latach bardzo wyraźnie wzrosła liczba renegocjowanych przez Rzeczpospolitą Polską konwencji w sprawie unikania podwójnego opodatkowania i zapobiegania uchylaniu się od opodatkowania w zakresie podatków od dochodu i majątku (dalej: umowy o unikaniu podwójnego opodatkowania). Pod względem liczby zawartych czy renegocjowanych umów o unikaniu podwójnego opodatkowania obecny okres można porównać jedynie z początkiem lat 90 . XX w. ${ }^{2} \mathrm{~W}$ latach 2008-2011 Polska renegocjowała siedem takich umów ${ }^{3}$ oraz zawarła cztery nowe 4 . Ponadto, obecnie trwają prace nad renegocjowaniem kolejnych 22 umów, w tym ze Stanami Zjednoczonymi czy Malezją, a protokół do umowy z Cyprem został podpisany 22 marca 2012 r. Tak znacząca intensyfikacja prac w zakresie negocjowania umów o unikaniu podwójnego opodatkowania może wzbudzać istotne zainteresowanie samym zjawiskiem jako takim, a także jego przyczynami i efektami. Niniejszy artykuł ma na celu analizę tego zjawiska poprzez przedstawienie przesłanek zawierania, a w szczególności renegocjowania przez Polskę umów o unikaniu podwójnego opodatkowania, zamierzonych celów, procedury prowadzenia negocjacji oraz aktualnych trendów w tym zakresie.

* Mgr Kamil Dybiec - Katedra Prawa Finansowego, Wydział Prawa i Administracji, Uniwersytet im. Adama Mickiewicza w Poznaniu.

${ }^{1}$ Autor niniejszego referatu dziękuje Panu Mariuszowi Każuchowi - Zastępcy Dyrektora Departamentu Polityki Podatkowej Ministerstwa Finansów RP za pomoc w przygotowaniu referatu, w szczególności udzielenie informacji dotyczących praktycznej strony negocjowania przez Rzeczypospolitą Polską umów o unikaniu podwójnego opodatkowania.

${ }^{2}$ Z 89 wszystkich podpisanych dotąd przez Polskę umów o unikaniu podwójnego opodatkowania, aż 46 przypada na lata 1991-1997. Niektóre z nich, z Nigerią, Urugwajem i Zambią, nigdy nie weszły w życie.

${ }^{3}$ Z Austrią (2008), Danią (2009), Finlandią (2009), Norwegią (2009), Szwajcarią (2010), Czechami (2011) oraz Maltą (2011).

${ }^{4}$ Z Katarem (2008), Arabią Saudyjską (2011), Jersey (2011) i Wyspą Man (2011). Nastąpiło także sprostowanie błędu w umowie z Meksykiem w zakresie art. 11 ust. 2 lit. a. 


\section{Przesłanki zawierania umów w sprawie unikania podwójnego opodatkowania}

Wzrost międzynarodowej wymiany handlowej i liczby zawieranych transakcji handlowych, z jednej strony, oraz stosowane przez państwa sposoby opodatkowania podatkami od dochodu, z drugiej - spowodowały, że zaczął pojawiać się problem podwójnego opodatkowania dochodu (majątku). Zjawisko to, w sensie prawnym, rozumiane jest jako wysuwanie roszczeń podatkowych do tego samego dochodu u tej samej osoby przez dwa (lub więcej) państwa ${ }^{5}$. Państwa stosują bowiem zasadniczo dwa sposoby opodatkowania dochodu, opodatkowując cały dochód uzyskany przez swoich rezydentów (ang. worldwide taxation) lub dochody uzyskane w danym państwie zarówno przez rezydentów, jak i nierezydentów (ang. source taxation). Najczęściej obydwie metody stosowane są jednocześnie. W najprostszej postaci, jeżeli państwo A stosuje pierwszą metodę, a państwo B drugą, to dochód uzyskany w państwie B przez rezydenta państwa A mógłby zostać opodatkowany w całości zarówno w państwie A, jak i w państwie B (podwójne opodatkowanie). Sytuacja taka znacznie ograniczałaby jednak opłacalność handlu międzynarodowego, stanowiąc istotną barierę dla jego rozwoju. Dostrzegając ten problem, państwa zawierają z innymi państwami umowy o unikaniu podwójnego opodatkowania, które są niczym innym, jak normami kolizyjnymi pozwalającymi na ustalenie, któremu państwu i w jakim zakresie przysługuje roszczenie do opodatkowania określonego dochodu określonej osoby. W konsekwencji podatnicy uzyskują pewność - gdzie, w jakim zakresie i według jakich zasad opodatkowane będą osiągane przez nich dochody. Jednocześnie, w celu zabezpieczenia interesu fiskalnego, umowy te zawierają zazwyczaj klauzule dotyczące wzajemnej współpracy i wymiany informacji przez organy podatkowe umawiających się państw w celu zapobiegania uchylaniu się od opodatkowania ${ }^{6}$. Potrzeba ujednolicenia postanowień umów zawieranych przez różne państwa doprowadziła do opracowania tekstów modelowych umów przez Organizację Współpracy Gospodarczej i Rozwoju (Modelowa Konwencja OECD w sprawie podatku od dochodu i majątku ${ }^{7}$ ) oraz Organizację Narodów Zjednoczonych (Modelowa umowa ONZ o unikaniu podwójnego opodatkowania pomiędzy państwami rozwiniętymi i państwami rozwijającymi się ${ }^{8}$ ). Umowy zawierane przez Rzeczpospolitą Polską oparte są na postanowieniach Modelowej

${ }^{5} \mathrm{~W}$ sensie ekonomicznym podwójne opodatkowanie rozumiane jest jako nałożenie w dwóch państwach porównywalnych podatków na różnych podatników z tytułu tego samego przedmiotu opodatkowania (m.in. M. Jamroży, Opodatkowanie spótki osobowej, Warszawa 2005, s. 10).

${ }^{6}$ Szerzej na ten temat: Manual for the Negotiation of Bilateral Tax Treaties between Developed and Developing Countries, 2003 s. 11-19; http://unpan1.un.org/intradoc/groups/public/documents/un/unpan008579.pdf (dostęp: 13.02.2012).

${ }^{7}$ Szerzej na temat Modelowej Konwencji OECD: B. Brzeziński (red.), Model Konwencji OECD. Komentarz, Warszawa 2010, s. 100-102.

${ }^{8}$ Szerzej na temat Modelowej Konwencji ONZ: D. Mączyński, Międzynarodowa wspótpraca w sprawach podatkowych, Warszawa 2009, s. 48-52. 
Konwencji OECD. Na marginesie należy zauważyć, iż choć umowy o unikaniu podwójnego opodatkowania mają co do zasady charakter dwustronny, to spotykane są także umowy wielostronne, jak np. umowa z 1996 r. o unikaniu podwójnego opodatkowania zawarta pomiędzy państwami nordyckimi 9 .

Nie można nie dostrzec, że o ile w latach 90. ubiegłego wieku Polska przede wszystkim zawierała nowe umowy, o tyle obecnie Departament Polityki Podatkowej w Ministerstwie Finansów skupia się przede wszystkim na renegocjowaniu umów już zawartych. Pozwala to na postawienie tezy, iż Polska posiada obecnie optymalną „,sieć” umów, dzięki której problem podwójnego opodatkowania w relacjach z najważniejszymi partnerami handlowymi został wyeliminowany. Umowy z Katarem (2008) czy Arabią Saudyjską (2011) oraz prace nad umową z Turkmenistanem stanowią przykład uzupełnienia istniejącej już „sieci” w odpowiedzi na zmieniającą się sytuację polityczną i gospodarczą ${ }^{10}$. Liczba renegocjowanych umów wynika natomiast głównie z trzech przyczyn:

1) konieczności dostosowania postanowień umów (w szczególności zawartych jeszcze w latach 70. ubiegłego wieku) do aktualnej sytuacji gospodarczej,

2) dążenia do ujednolicenia stosowanych rozwiązań, w tym w zakresie metody unikania podwójnego opodatkowania,

3) konieczności przeciwdziałania uchylaniu się od opodatkowania i unikaniu opodatkowania.

Spośród obecnie obowiązujących 83 umów ${ }^{11}$ aż 13 obowiązuje w wersji uzgodnionej jeszcze przed 1990 r. Dotyczy to m.in. umów z tak istotnymi dla Polski partnerami handlowymi, jak Stany Zjednoczone (1974), Francja (1975), Malezja (1977), Hiszpania (1979), Japonia (1980), Włochy (1975), Kanada (1987), Chiny (1988) czy Indie (1989). Zaszłe od tego czasu zmiany gospodarcze, a także zmiany w systemach podatkowych państw wymuszają dostosowanie postanowień zawartych umów do aktualnej sytuacji.

W przypadku umów z państwami członkowskimi Unii Europejskiej oraz EFTA zdaje się zarysowywać trend ujednolicania stosowanych metod unikania podwójnego opodatkowania. Początku tego trendu można upatrywać w umowie z Wielką Brytanią (2006), kiedy to na skutek zmasowanej kampanii medialnej Polska zrezygnowała ze stosowania metody zaliczenia proporcjonalnego na rzecz wyłączenia z progresją ${ }^{12}$. Metoda proporcjonalnego zaliczenia polega na zalicze-

9 Stronami tej umowy są Szwecja, Dania, Finlandia, Norwegia oraz Islandia.

${ }^{10}$ Umowę z Katarem można powiązać z planami budowy terminala gazowego w Świnoujściu i założeniami, według których katarskie przedsiębiorstwa miały być jednymi z głównych dostawców tego surowca. Umowę z Arabią Saudyjską można natomiast powiązać z faktem występowania w tym kraju nadwyżki kapitału i zainteresowania inwestowaniem tego kapitału w Polsce. Singapur stanowi natomiast jedno z istotnych światowych centrów finansowych.

${ }^{11}$ Umowy z Arabią Saudyjską oraz Jersey podpisane w 2011 r. nie weszły jeszcze w życie.

${ }_{12}$ Za wyjątkiem dochodów przewidzianych w art. 10 (dywidendy), art. 11 (odsetki), art. 12 (należności licencyjne) i art. 13 (zyski majątkowe) umowy o unikaniu podwójnego opodatkowania zawartej z Wielką Brytanią. 
niu przez państwo rezydencji podatnika na rzecz własnego roszczenia podatkowego podatku zapłaconego w drugim państwie, jednakże w kwocie nie większej od kwoty podatku, jaki byłby należny od tego dochodu w państwie rezydencji. Natomiast metoda wyłączenia z progresją polega na tym, iż dochód uzyskany w jednym z umawiających się państw przez osobę mającą miejsce zamieszkania lub siedzibę w drugim państwie zwalnia się z opodatkowania w państwie rezydencji, jednakże dla ustalenia podatku należnego od dochodu uzyskanego w państwie rezydencji stosuje się stawkę procentową podatku obliczoną dla całego docho$\mathrm{du}^{13}$. Przyjęcie w umowie z Wielką Brytanią metody wyłączenia z progresją, która w oczach opinii publicznej uznana została za metodę korzystniejszą dla podatnika, co zresztą oparte było na częściowo błędnych przesłankach ${ }^{14}$, spowodowało natomiast podobne oczekiwania wobec umów z innymi krajami. W konsekwencji analogicznej zmiany dokonano w umowach z Austrią (2008), Danią (2009), Finlandią (2009), Norwegią (2009) oraz Czechami (2011), a w 2012 r. ma nastąpić w tym zakresie także zmiana umowy z Islandią. Zmiany te, w szczególności w kontekście utraty możliwości skompensowania przez polskich przedsiębiorców straty poniesionej $\mathrm{z}$ prowadzonej $\mathrm{w}$ tych państwach działalności gospodarczej (zakładu) z zyskami osiąganymi w Polsce, należy ocenić jako w rzeczywistości niekorzystne dla podatników ${ }^{15}$.

Nie mniej ważną przyczyną renegocjacji umów czy zawierania nowych jest konieczność przeciwdziałania zjawiskom uchylania się od opodatkowania i unikania opodatkowania. Należy bowiem zauważyć, że celem zawierania takich umów jest eliminacja zjawiska podwójnego opodatkowania, a nie częściowe czy całkowite wyeliminowanie opodatkowania jako takiego. Tymczasem odpowiednio zaaranżowane przez podatników schematy pozwalają w określonych przypadkach na osiągnięcie takich właśnie efektów. Na gruncie międzynarodowego prawa podatkowego uchylanie się od opodatkowania rozumiane jest jako podejmowanie niezgodnych z prawem działań w celu ukrycia faktycznie osiągniętych dochodów, m.in. poprzez lokowanie ich w państwach, które odmawiają organom podatkowym państwa rezydencji podatnika udzielenia informacji dotyczących zgromadzonych na jego terytorium środków podatnika ${ }^{16}$. W celu zminimalizowania

13 Szerzej na temat metod unikania podwójnego opodatkowania: J. Banach, Polskie umowy o unikaniu podwójnego opodatkowania, Warszawa 2000, s. 337-351.

14 Problem podwójnego opodatkowania w ogóle nie powstawał w przypadku osób, które na stałe przeniosły się do Wielkiej Brytanii i tam uzyskiwały dochody, gdyż to właśnie Wielka Brytania stała się w ich przypadku zarówno państwem rezydencji podatkowej, jak i państwem źródła uzyskiwanych dochodów.

$15 \mathrm{~W}$ podpisanym 22 marca 2012 r. protokole do umowy z Cyprem jako metodę unikania podwójnego opodatkowania w zakresie zysków przedsiębiorstw przewidziano zaliczenie proporcjonalne, co eliminuje ten problem po stronie przedsiębiorców.

16 Szerzej na temat uchylania się od opodatkowania i unikania opodatkowania: R. Sowiński, Uchylanie się od opodatkowania: przyczyny, skutki i sposoby zapobiegania zjawisku, Poznań 2009, s. 11-17. 
negatywnych skutków tego zjawiska Polska dąży do wprowadzenia w umowach klauzuli pełnej wymiany informacji. W tym zakresie za przełom można uznać zmianę umowy ze Szwajcarią. Obecnie polski fiskus ma zagwarantowany dostęp do informacji o środkach zgromadzonych przez polskich rezydentów w szwajcarskich bankach, z tym jednak ograniczeniem, iż dotyczy to informacji za okresy przypadające dopiero po wejściu w życie protokołu o zmianie umowy ze Szwajcarią, tj. począwszy od 1 stycznia 2012 r. ${ }^{17}$ Ponadto, wykluczone jest tzw. spontaniczne gromadzenie informacji o podatnikach (ang. fishing expeditions). Polskie organy podatkowe nie mogą zatem kierować do organów szwajcarskich generalnych zapytań dotyczących wszystkich polskich rezydentów czy też określonych rezydentów, jeżeli nie ma po temu uzasadnienia, tzn. jeżeli nie toczy się przeciw nim postępowanie podatkowe w Polsce. Należy natomiast zauważyć, iż powzięcie przez polskie organy podatkowe informacji o środkach zgromadzonych przez polskiego rezydenta w Szwajcarii daje podstawę do wszczęcia postępowania w sprawie wydania decyzji o opodatkowaniu dochodów z nieujawnionych źródeł i przerzucenia w ten sposób ciężaru dowodu, w zakresie wykazania źródła pochodzenia tych środków, na podatnika. Znaczącymi sukcesami na polu eliminowania możliwości uchylania się od opodatkowania są także umowy z Jersey (2011), Wyspą Man $(2011)^{18}$, a także z Guernsey ${ }^{19}$, uzupełnione o umowy o wymianie informacji w sprawach podatkowych.

Departament Polityki Podatkowej Ministerstwa Finansów obrał sobie za cel także przeciwdziałanie unikaniu opodatkowania. Unikanie opodatkowania, w przeciwieństwie do uchylania się od opodatkowania, polega na podejmowaniu działań w celu zmniejszenia ciężarów podatkowych, jednakże przy użyciu legalnych środków, a zatem pozbawione jest ono cechy bezprawności. Opiera się ono na założeniu, iż każdy jest uprawniony, w miarę swoich możliwości, do ułożenia własnych spraw w taki sposób, ażeby uzyskać efekt w postaci mniejszego obciążenia podatkowego, niż miałoby to miejsce w przypadku ułożenia tych spraw w inny sposób ${ }^{20}$. Unikanie opodatkowania realizowane jest w szczególności przy użyciu określonych schematów optymalizacji podatkowej. Tworzenie takich

17 Art. XII lit. d Protokołu z 20 kwietnia 2010 r. o zmianie Konwencji między Rzeczypospolitą Polską a Konfederacją Szwajcarską w sprawie unikania podwójnego opodatkowania w zakresie podatków od dochodu i majątku z 2 września 1991 r.

18 Umowy te odbiegają w swej treści od Modelowej Konwencji OECD, w szczególności nie zawierają postanowień dotyczących eliminacji podwójnego opodatkowania w zakresie zysków przedsiębiorstw, sprzedaży majątku, dywidend, odsetek czy należności licencyjnych.

19 W 2012 r. Ministerstwo Finansów planuje także podpisać umowy z Andorą i San Marino.

20 Parafraza wypowiedzi Lorda Tomlin w sprawie IRC vs. Duke of Westminster (1936), cyt. za: Manual for the Negotiation ..., s. 34: „Every man is entitled, if he can, to order his affairs so that tax attaching under the appropriate Acts is less than it would be otherwise. If he succeeds in ordering them so as to secure this result, than, however unappreciative the Commissioners of Inland Revenue or his fellow taxpayers may be of his ingenuity, he cannot be compelled to pay an increased tax". 
schematów umożliwiają zawarte w niektórych umowach postanowienia, pozwalające na obniżenie obciążeń podatkowych w Polsce dzięki sztucznemu ,wyprowadzeniu" za granicę określonych transakcji dotyczących polskich podmiotów gospodarczych czy majątku znajdującego się w Polsce. Dotyczy to chociażby faktycznego przenoszenia własności nieruchomości położonych w Polsce, które odbywa się nie poprzez bezpośrednią ich sprzedaż, ale pośrednio - poprzez sprzedaż udziałów spółce zagranicznej będącej „,właścicielką” (jedynym udziałowcem) polskiej spółki, do której należy nieruchomość. Postanowieniem stymulującym tworzenie schematów optymalizacyjnych jest niewątpliwie klauzula tax sparing, przyjęta także przez Polskę w niektórych umowach o unikaniu podwójnego opodatkowania. Sztandarowym przykładem w tym zakresie jest umowa z Cyprem, w przypadku której (w związku z zastosowaniem cypryjskiego prawa podatkowego) klauzula ta pozwala na obniżenie opodatkowania dywidendy wypłacanej polskiemu rezydentowi przez spółkę cypryjską z 19\% do $9 \%{ }^{21}$. Należy jednak zauważyć, iż klauzulę tax sparing zawierają także m.in. umowy zawarte przez Polskę ze Słowacją czy Ukrainą. Wyeliminowane zostały już natomiast m.in. z umów z Maltą i Czechami.

$\mathrm{Z}$ uwagi na ograniczone zasoby osobowe i rzeczowe Ministerstwo Finansów nie jest w stanie analizować wszystkich działań rezydentów podejmowanych w celu unikania opodatkowania poprzez optymalizację podatkową z wykorzystaniem umów o unikaniu podwójnego opodatkowania. Departament Polityki Podatkowej MF na bieżąco monitoruje natomiast informacje pojawiające się w mediach czy Internecie, a także analizuje sygnały i informacje otrzymane od organów kontroli. Ponadto, analizowane są wydane przez ministra finansów (upoważnionych dyrektorów Izb Skarbowych) indywidualne interpretacje podatkowe, publikowane w Systemie Informacji Podatkowej. Interpretacje te, choć oczywiście nie odzwierciedlają wszystkich działań podejmowanych przez podatników w celu unikania opodatkowania, stanowią swoisty „,papierek lakmusowy”. Podatnik, chcąc uzyskać potwierdzenie podatkowej „opłacalności” określonego schematu optymalizacji, jest bowiem zmuszony schemat ten w znacznej części ujawnić.

\section{Procedura negocjowania i zawierania umów}

Zawieranie umów o unikaniu podwójnego opodatkowania, a także ich renegocjowanie, podlega określonemu reżimowi prawnemu przyjętemu $\mathrm{w}$ prawie wewnętrznym, jak również przyjętym w prawie międzynarodowym zasadom i zwyczajom, które jednak pozostają poza zakresem niniejszego artykułu.

${ }^{21}$ Szerzej na ten temat: A. Pęczyk-Tofel, M. S. Tofel, Tax sparing przy wyplacie dywidendy z Cypru oraz zwolnienie z opodatkowania w Polsce wynagrodzenia dyrektora, „Monitor Podatkowy" 2009, nr 2. 
Procedura zawierania przez Polskę umów międzynarodowych została uregulowana w Konstytucji Rzeczypospolitej Polskiej22 , a także w ustawie z 14 kwietnia 2000 r. o umowach międzynarodowych ${ }^{23}$ oraz wydanym na jej podstawie rozporządzeniu Rady Ministrów z 28 sierpnia 2000 r. w sprawie wykonania niektórych przepisów ustawy o umowach międzynarodowych ${ }^{24}$.

$\mathrm{Z}$ uwagi na to, iż umowy o unikaniu podwójnego opodatkowania dotyczą praw i obowiązków obywatelskich określonych w Konstytucji RP (art. 84 Konstytucji), a także spraw uregulowanych w ustawie i w których Konstytucja wymaga ustawy (art. 217 Konstytucji), ich ratyfikacja i ewentualne wypowiedzenie wymaga uprzedniej zgody wyrażonej w ustawie (art. 89 ust. 1 pkt 2 i 5 Konstytucji). Z tego względu postanowienia zawartych przez Polskę umów o unikaniu podwójnego opodatkowania, po ich ogłoszeniu w Dzienniku Ustaw RP, stanowią część krajowego porządku prawnego i są bezpośrednio stosowane (art. 91 ust. 1 Konstytucji), a w przypadku, gdy nie da się ich pogodzić z postanowieniami polskiej ustawy podatkowej, mają one pierwszeństwo przed postanowieniami tej ustawy (art. 91 ust. 2 Konstytucji). Aby jednak mogło dojść do ratyfikacji umowy, uzgodnienie jej treści musi nastąpić w sposób przewidziany w ustawie o umowach międzynarodowych i wydanym na jej podstawie rozporządzeniu.

Przepisy ustawy o umowach międzynarodowych określają tryb zawierania, ratyfikowania, ogłaszania, wykonywania, wypowiadania i dokonywania zmian zakresu obowiązywania umów międzynarodowych, w tym umów o unikaniu podwójnego opodatkowania (art. 1 ustawy). Zawarcie czy renegocjacja określonej umowy wymaga przede wszystkim podjęcia w tym zakresie stosownej decyzji w Ministerstwie Finansów, a konkretnie w Departamencie Polityki Podatkowej Ministerstwa Finansów, który odpowiada m.in. za przygotowanie założeń polityki podatkowej, analizę funkcjonowania systemu podatkowego, a także prowadzi międzynarodową współpracę w zakresie polityki podatkowej z innymi państwami, w tym negocjuje umowy o unikaniu podwójnego opodatkowania. Rozpoczęcie procesu negocjacji wymaga przygotowania przez Departament Polityki Podatkowej projektu umowy (zmiany umowy) wraz z uzasadnieniem oraz instrukcji negocjacyjnej. Uzasadnienie powinno wskazywać w szczególności na potrzebę i cel zawarcia (renegocjacji) umowy, różnice pomiędzy dotychczasowym i planowanym stanem prawnym oraz przewidywane skutki społeczne, gospodarcze, finansowe i prawne związane $\mathrm{z}$ wejściem umowy w życie (§ 2 ust. 5 wspomnianego rozporządzenia). Projekt wraz z instrukcją podlegają zatwierdzeniu przez ministra finansów, a następnie uzgodnieniu z ministrem spraw zagranicznych, innymi zainteresowanymi ministrami oraz prezesem Rządowego Centrum Legislacji. Uzgodniona instrukcja wraz z projektem przedkładane są Prezesowi Rady

${ }^{22}$ Dz. U. Nr 78, poz. 483 z dnia 16 lipca 1997 r.

${ }_{23}$ Dz. U. Nr 39, poz. 443 z dnia 17 maja 2000 r.

${ }^{24}$ Dz. U. Nr 79, poz. 891 z dnia 22 września 2000 r. 
Ministrów wraz z wnioskiem o udzielenie zgody na rozpoczęcie negocjacji (art. 5 ust. 1 ustawy o umowach międzynarodowych). Instrukcja negocjacyjna powinna być na tyle elastyczna, aby umożliwiała dojście do porozumienia z przedstawicielami drugiego państwa oraz modyfikację pierwotnego stanowiska bez konieczności uzyskania ponownego jej zatwierdzenia. Prezes Rady Ministrów wyznacza organ właściwy do prowadzenia negocjacji oraz zakres jego upoważnienia (art. 5 ust. 2 ustawy o umowach międzynarodowych).

Od strony praktycznej przystąpienie do negocjacji czy renegocjacji konkretnej umowy o unikaniu podwójnego opodatkowania wymaga przede wszystkim odpowiedniego przygotowania ze strony negocjatorów. Dotyczy to w szczególności poznania systemu prawa podatkowego państwa, z którym umowa ma być zawarta czy renegocjowana oraz określenia potencjalnych zagrożeń. Przez zagrożenia należy w szczególności rozumieć możliwość udostępnienia polskim rezydentom mechanizmów, które mogą posłużyć w celu unikania opodatkowania lub uchylania się od opodatkowania. Przy czym należy zauważyć, iż duże prawdopodobieństwo umożliwienia polskim rezydentom uchylania się od opodatkowania na skutek zawarcia umowy z państwem stosującym szkodliwe praktyki podatkowe praktycznie eliminuje sens i celowość zawarcia takiej umowy. Pogłębiona analiza systemu podatkowego drugiego państwa pozwala na przyjęcie określonych założeń oraz na przedstawienie stanowiska wraz z projektem umowy drugiej stronie. Wymiana stanowisk jeszcze przed spotkaniem przedstawicieli obydwu państw pozwala na ocenę, w jakim zakresie stanowiska stron są zbieżne, a w jakim wymagają dalszych uzgodnień i wypracowania kompromisu, tj. na przygotowanie gruntu pod spotkanie obydwu stron. Spotkania, zgodnie ze zwyczajem międzynarodowym, odbywają się najczęściej na zasadzie wizyt i rewizyt, których liczba uzasadniona jest stopniem zbliżenia stanowisk stron. Uzgodnienie ostatecznego projektu umowy czy też zakresu zmiany obowiązującej umowy musi być satysfakcjonujące dla obydwu państw. W innym przypadku w ogóle nie dojdzie do zawarcia umowy albo pojawi się ryzyko wypowiedzenia przez jedno z państw umowy już zawartej. Szczegóły prowadzonych negocjacji, w tym treść negocjowanych postanowień, wobec art. 5 ust. 3 pkt 1 i ust. 5 ustawy o ochronie informacji niejawnych ${ }^{25}$, nie podlegają na tym etapie upublicznieniu.

Po wynegocjowaniu tekstu umowy czy zmiany umowy o unikaniu podwójnego opodatkowania z drugim państwem, minister finansów powinien uzgodnić tekst umowy z ministrem spraw zagranicznych oraz innymi zainteresowanymi

${ }^{25}$ Dz. U. Nr 182, poz. 1228 z 2010 r. Art. 5 ust. 3 pkt 1 tejże ustawy brzmi: „Informacjom niejawnym nadaje się klauzulę «poufne», jeżeli ich nieuprawnione ujawnienie spowoduje szkodę dla Rzeczypospolitej Polskiej przez to, że: utrudni prowadzenie bieżącej polityki zagranicznej Rzeczypospolitej Polskiej”. Art. 5 ust. 5 tejże ustawy brzmi: „Informacje niejawne przekazane przez organizacje międzynarodowe lub inne państwa na podstawie umów międzynarodowych oznacza się polskim odpowiednikiem posiadanej klauzuli tajności”. 
ministrami. Po uzgodnieniu, minister finansów składa Radzie Ministrów wniosek o udzielenie zgody na podpisanie umowy międzynarodowej wraz z załącznikami wskazanymi $\mathrm{w} \S 5$ ust. 1 wspomnianego rozporządzenia, $\mathrm{w}$ tym $\mathrm{z}$ opinią o zgodności umowy z prawem Unii Europejskiej. Podpisana umowa jest następnie przedkładana przez ministra spraw zagranicznych Radzie Ministrów $\mathrm{z}$ wnioskiem o jej ratyfikację oraz m.in. projektem ustawy wyrażającej zgodę na ratyfikację umowy wraz $\mathrm{z}$ uzasadnieniem. Wyrażenie zgody na ratyfikację wymaga uchwalenia przez Sejm ustawy większością 2/3 głosów w obecności co najmniej połowy ustawowej liczby posłów oraz przez Senat większością 2/3 głosów w obecności co najmniej połowy ustawowej liczby senatorów (art. 90 ust. 2 Konstytucji). Możliwe jest także podjęcie przez Sejm uchwały w sprawie wyrażenia zgody na ratyfikację umowy o unikaniu podwójnego opodatkowania w referendum ogólnokrajowym (art. 90 ust. 3 Konstytucji). Sytuacja taka nie miała jednak, jak do tej pory, miejsca. Po wyrażeniu zgody przez Sejm i Senat, Rada Ministrów przedkłada Prezydentowi RP umowę do ratyfikacji. Ratyfikowana umowa o unikaniu podwójnego opodatkowania publikowana jest niezwłocznie w Dzienniku Ustaw. Za wykonanie obowiązków i korzystanie z praw przewidzianych w umowie dla Rzeczypospolitej Polskiej odpowiedzialny jest minister finansów.

Zmiana zawartej umowy o unikaniu podwójnego opodatkowania wymaga ponownego przeprowadzenia całej procedury negocjacyjnej, w tym przedłożenia Radzie Ministrów przez ministra finansów za pośrednictwem ministra spraw zagranicznych wniosku (po uzgodnieniu z zainteresowanymi ministrami, najczęściej ministrem gospodarki) o wyrażenie zgody na renegocjowanie umowy. Zmiana zakresu obowiązywania umowy, zazwyczaj w formie protokołu do umowy, podobnie jak sama umowa, wymaga uzyskania zgody Sejmu i Senatu na jej ratyfikację, wyrażonej w ustawie, a następnie ratyfikowania przez Prezydenta RP i ogłoszenia w Dzienniku Ustaw.

Wypowiedzenie umowy o unikaniu podwójnego opodatkowania dokonywane jest natomiast przez Prezydenta RP i wymaga ogłoszenia w Dzienniku Ustaw. Wypowiedzenie umowy musi być poprzedzone wyrażeniem zgody przez Sejm i Senat w formie ustawy. Samo zainicjowanie procesu wypowiedzenia umowy, podobnie jak w przypadku jej zmiany, wymaga poczynienia przez ministra finansów uzgodnień z zainteresowanymi ministrami i złożenia Radzie Ministrów stosownego wniosku za pośrednictwem ministra spraw zagranicznych.

Jak wynika z powyższego, procedura negocjowania, zawierania, renegocjowania i wypowiadania umów o unikaniu podwójnego opodatkowania jest w Polsce stosunkowo czasochłonna i znacząco sformalizowana. Jednakże, z uwagi na zakres regulowanych tymi umowami spraw (art. 84 i 217 Konstytucji), wymogi te należy oceniać jako uzasadnione. 


\section{Podsumowanie}

Fakt prowadzenia przez Departament Polityki Podatkowej Ministerstwa Finansów intensywnych prac nad renegocjowaniem zawartych przez Polskę umów o unikaniu podwójnego opodatkowania pozwala na skonstatowanie, iż Polska, z jednej strony, wykształciła już dostatecznie rozwiniętą sieć takich umów, z drugiej natomiast - wskazuje na konieczność dostosowania tych umów do zmieniających się realiów gospodarczych i „uszczelnienia” systemu w celu zapobieżenia utraty dochodów budżetowych. Wprawdzie brak jest publicznie dostępnych danych dotyczących tego, ile polski budżet traci co roku na wykorzystywaniu umów o unikaniu podwójnego opodatkowania dla optymalizacji podatkowej, jednak intensyfikacja działań Ministerstwa Finansów w celu ich zmiany może świadczyć o tym, iż są to kwoty znaczące.

W dalszej kolejności, obok wyraźnej tendencji do „uszczelniania” systemu, można także wyraźnie zaobserwować dążenie do ujednolicania, przynajmniej w umowach z krajami Unii Europejskiej, stosowanych metod unikania podwójnego opodatkowania. Działania takie, i to niezależnie od oceny wyboru samej metody, uważam za uzasadnione i słuszne. Nie ma bowiem powodu dla stosowania odmiennych metod unikania podwójnego opodatkowania w przypadku polskich rezydentów uzyskujących dochody w różnych państwach UE.

Wydaje się, iż wobec rosnącej liczby wniosków o wydanie indywidualnych interpretacji przepisów prawa podatkowego, szczególnie z udziałem spółek osobowych założonych w państwach, z którymi Polska ma zawarte umowy o unikaniu podwójnego opodatkowania, będzie to największe wyzwanie, z jakim przyjdzie się zmierzyć Ministerstwu Finansów w nadchodzących latach w tym zakresie. Problemy, jakie pojawiają się w przypadku spółek osobowych na gruncie stosowania umów o unikaniu podwójnego opodatkowania, zostały obszernie opisane już w raporcie OECD z 1999 r. ${ }^{26}$ i dotyczą w szczególności odmiennego traktowania spółki osobowej na gruncie podatków dochodowych - jako podmiotu transparentnego bądź posiadającego podmiotowość podatkową. Choć od czasu publikacji wspomnianego raportu OECD upłynęło kilkanaście lat, problemy te nie tylko nadal pozostają aktualne, ale coraz bardziej nabrzmiewają. Być może właściwym rozwiązaniem w tym zakresie byłoby przyznanie spółkom osobowym podmiotowości podatkowej na gruncie podatku dochodowego, nic jednak nie wskazuje, aby taka zmiana miała nastąpić w najbliższym czasie.

${ }^{26}$ The Application of the OECD Model Tax Convention to Partnerships, 1999; www.oecdbookshop.org/oecd/display.asp?lang=EN\&sfl=identifiers\&st1=231999521p1 (dostęp: 20.03.2012). 